\title{
Vertical distributions of nitrogen-fixing phylotypes at Stn ALOHA in the oligotrophic North Pacific Ocean
}

\author{
Matthew J. Church ${ }^{1,3, *}$, Bethany D. Jenkins ${ }^{1}$, David M. Karl ${ }^{2}$, Jonathan P. Zehr ${ }^{1}$ \\ ${ }^{1}$ Ocean Sciences Department, University of California at Santa Cruz, Earth and Marine Sciences Building, Santa Cruz, \\ California 95064, USA \\ ${ }^{2}$ Department of Oceanography, University of Hawaii, Honolulu, Hawaii 96822, USA \\ ${ }^{3}$ Present address: Department of Oceanography, University of Hawaii, Honolulu, Hawaii 96822, USA
}

\begin{abstract}
In large areas of the world's oceans, biological dinitrogen $\left(\mathrm{N}_{2}\right)$ fixation supports a significant fraction of ecosystem productivity; to date, however, there is little information on the abundances of specific diazotrophs in the ocean. In this study, the vertical distributions of several different groups of $\mathrm{N}_{2}$-fixing bacteria were examined using quantitative polymerase chain reaction (QPCR) amplification of group-specific dinitrogenase reductase (nifH) genes from Stn ALOHA in the subtropical North Pacific Ocean. Depth distributions $(<200 \mathrm{~m})$ of 3 cyanobacterial nifH phylotypes and 1 previously uncharacterized Cluster III nifH phylotype were evaluated. The nifH-containing cyanobacteria included sequence-types similar to Trichodesmium spp. and 2 nifH sequences closely related to unicellular cyanobacteria (termed Groups A and B). The Group A cyanobacteria (most closely related to Cyanothece sp.) were the most abundant of all phylotypes examined, comprising $2 \times 10^{5}$ nifH gene copies $\mathrm{l}^{-1}$ in the high-irradiance $\left(>700 \mu \mathrm{mol}\right.$ quanta $\left.\mathrm{m}^{-2} \mathrm{~s}^{-1}\right)$, nitrate-depleted $\left(<10 \mathrm{nmol} \mathrm{l}^{-1}\right)$ upper-ocean waters. Group B cyanobacterial phylotypes (most closely related to Crocosphaera watsonii) demonstrated a depth distribution similar to Group A, but Group B nifH abundance was considerably lower, averaging $2 \times 10^{3}$ nifH gene copies $\mathrm{l}^{-1}$ in the upper photic zone. The abundance of Trichodesmium spp. ranged from $1 \times 10^{3}$ to $7 \times 10^{3}$ nifH gene copies $\mathrm{l}^{-1}$ in the upper ocean, declining to $<100$ nifH gene copies $\mathrm{l}^{-1}$ below the mixed layer $(\sim 82 \mathrm{~m})$. The Cluster III nifH phylotype was the most abundant nifH phylotype in the dimly lit $\left(<12 \mu\right.$ mol quanta $\left.\mathrm{m}^{-2} \mathrm{~s}^{-1}\right)$ lower photic zone $(>100 \mathrm{~m})$. These results revealed differences in the depth distributions of $\mathrm{N}_{2}$-fixing plankton at Stn ALOHA, and suggest that unicellular diazotrophs comprise a significant component of plankton biomass in this oligotrophic marine ecosystem.
\end{abstract}

KEY WORDS: Nitrogen fixation · Bacterial diversity $\cdot$ Quantitative PCR $\cdot$ Hawaii Ocean $\cdot$ Time-series

\section{INTRODUCTION}

Ocean biogeochemistry is largely controlled by the metabolic activities of planktonic microorganisms. In many marine ecosystems, the bioavailability of nitrogen (N) regulates plankton production and carbon export (Dugdale \& Goering 1967, Eppley \& Peterson 1979). In the open ocean, plankton productivity is supported by both new and recycled forms of N (Eppley \& Peterson 1979). New $N$ inputs to the upper ocean include nitrate $\left(\mathrm{NO}_{3}{ }^{-}\right)$introduced across the thermocline, atmospheric deposition, and biological fixation of dinitrogen $\left(\mathrm{N}_{2}\right)$.
Direct measurements and biogeochemical proxies suggest that rates of $\mathrm{N}_{2}$-fixation may account for a significant fraction of the total $\mathrm{N}$ flux into open-ocean ecosystems (Michaels et al. 1996, Gruber \& Sarmiento 1997, Deutsch et al. 2001, Lee et al. 2002, Montoya et al. 2004) .

Biological $\mathrm{N}_{2}$-fixation is catalyzed by nitrogenase, a metal-cofactor enzyme that consists of 2 highly conserved proteins: an iron $(\mathrm{Fe})$-containing dinitrogenase reductase (or Fe protein), encoded by the nifH gene; and the molybdenum iron $(\mathrm{MoFe})$ dinitrogenase (or MoFe protein), encoded by the nifDK genes. Nitroge- 
nase is widely distributed among diverse Bacteria and Archaea, and evolved relatively early in prokaryote evolution (Zehr \& Capone 1996, Falkowski 1997); as a result, the nif genes appear useful for evaluating phylogenetic relationships among prokaryotes (Zehr \& Capone 1996, Falkowski 1997, Zehr et al. 2003).

Among the most conspicuous and well-studied of the oceanic $\mathrm{N}_{2}$-fixers are the filamentous, nonheterocystous cyanobacteria of the genus Trichodesmium, which play a globally significant role in ocean biogeochemistry (Carpenter 1983, Capone et al. 1997, Karl et al. 1997). In addition, endosymbiont $\mathrm{N}_{2}$-fixing cyanobacteria such as Richelia intracellularis, which live in association with marine diatoms, also appear to provide fixed nitrogen to the upper-ocean plankton assemblages (Venrick 1974, Weare et al. 1974, Villareal 1991, Carpenter et al. 1999). Until recently, unicellular cyanobacteria were not considered important contributors to oceanic $\mathrm{N}_{2}$-fixation; however, recent molecular-based techniques have identified 2 open-ocean nifH sequence-types (termed Groups A and B) that phylogenetically cluster with unicellular cyanobacteria (Zehr et al. 2001, Falcón et al. 2002, 2004), and both of these phylotypes have been found to express nifH, suggesting an active role for these groups in $\mathrm{N}_{2}$ fixation (Zehr et al. 2001, Falcón et al. 2004).

The nifH DNA sequences of Group A cyanobacteria are loosely related (82\% similar) to Cyanothece sp. ATCC51142, while the Group B nifH DNA sequences are 93 to $99 \%$ similar to marine Crocosphaera watsonii WH8501 (AF300829). Both Cyanothece sp. and marine C. watsonii are 2 to $10 \mu \mathrm{m}$ diameter, unicellular cyanobacteria that contain the accessory photosynthetic pigment phycoerythrin PE (Rippka et al. 2001). Unicellular cyanobacteria of morphology similar to Cyanothece sp. and $C$. watsonii have been observed in the open ocean (Campbell et al. 1997, Neveux et al. 1999, Falcón et al. 2004), and recent studies suggest that they may be important in open-ocean $\mathrm{N}_{2}$-fixation (Falcón et al. 2004, Montoya et al. 2004).

The subtropical North Pacific Ocean is one of the most expansive ecosystems on Earth (Karl 1999). At Stn ALOHA in the central North Pacific Ocean, surface water concentrations of nitrate and nitrite $\left[\mathrm{NO}_{3}{ }^{-}+\mathrm{NO}_{2}{ }^{-}\right]$ are typically $<10 \mathrm{nM}$. Nitrate input to the upper ocean is largely restricted to diffusion across the nitracline and advective fluxes via Rossby waves and mesoscale eddies (Karl 1999, Letelier et al. 2000, Sakamoto et al. 2004). Despite the paucity of inorganic nutrients to support plankton growth, nitrogen export at Stn ALOHA averages $103 \mathrm{mmol} \mathrm{N} \mathrm{m}^{-2} \mathrm{yr}^{-1}$, with up to one-half of this export supported by $\mathrm{N}_{2}$-fixation (Dore et al. 2002).

The TaqMan ${ }^{\circledR}$ 5'-fluorogenic exonuclease quantitative polymerase chain reaction (QPCR) assay has been used to assess the abundance and distribution of ecologically relevant marine prokaryotes (Suzuki et al. 2000, 2001, Short et al. 2004). In this study, we developed QPCR primers and probes to determine the abundances and vertical distributions of several nifH phylotypes observed at Stn ALOHA. QPCR primers and probes were developed to target Trichodesmium spp., and Group A and B cyanobacterial phylotypes, as well as a novel nifH Cluster III phylotype. Our results indicate that nifH genes are abundant in the upper ocean of the oligotrophic North Pacific Ocean.

\section{MATERIALS AND METHODS}

Sample collection, DNA extraction, and degenerate nifH PCR. Sampling for this study was conducted aboard the RV 'Kilo Moana' (KM 0210) during a research cruise to Stn ALOHA $\left(22^{\circ} 45^{\prime} \mathrm{N}, 158^{\circ} 00^{\prime} \mathrm{W}\right)$ from December 12 to 16,2002 . Water samples were collected from 9 depths $(5,25,45,75,100,125,150$, $175,200 \mathrm{~m}$ ) in the upper ocean using polyvinyl chloride bottles attached to a conductivity-temperaturedepth rosette sampler. Whole seawater was subsampled into 21 polycarbonate bottles and processed at sea. We sequentially filtered 11 seawater samples from each depth onto in-line $25 \mathrm{~mm}$ diameter, $10 \mu \mathrm{m}$ poresize Nylon filters, and onto $0.2 \mu \mathrm{m}$ pore-size Supor ${ }^{\circledR}$ filters (Pall Gelman). Seawater was pumped through the filters using a peristaltic pump and acid-washed silicon tubing. Upon completion of filtration, both the 0.2 and $10 \mu \mathrm{m}$ filters were removed from the Swinnex ${ }^{\circledR}$ filter holders (Millipore) and placed in $2 \mathrm{ml}$ centrifuge tubes containing $500 \mu$ l of Tris-EDTA (TE) (10 mM Tris$\mathrm{HCl}$ at $\mathrm{pH} 7.4 ; 1 \mathrm{mM}$ EDTA at $\mathrm{pH}$ 8.0). Centrifuge tubes were immediately frozen in liquid nitrogen and transported back to the shore-based laboratory for analyses.

Nucleic acids were extracted from the 0.2 and $10 \mu \mathrm{m}$ filters using the protocol described by Tillett \& Neilan (2000). Briefly, $500 \mu \mathrm{l}$ of potassium xanthogenate buffer ( $2 \% \mathrm{w} / \mathrm{v}$ potassium ethyl xanthogenate; $200 \mathrm{mM}$ Tris- $\mathrm{HCl}, \mathrm{pH} 7.4 ; 2$ mM EDTA, pH 8.0;2\% sodium dodecylsulfate; 1.6 M ammonium acetate) was added to centrifuge tubes containing filters and $500 \mu \mathrm{l} \mathrm{TE}$ buffer. Filters were incubated at $70^{\circ} \mathrm{C}$ for $120 \mathrm{~min}$. After extraction, the buffer containing extracted sample was removed from the tubes and transferred to new $2 \mathrm{ml}$ centrifuge tubes. Samples were vortexed briefly, placed on ice for $30 \mathrm{~min}$, and then centrifuged at room temperature at $10000 \times g$ for $10 \mathrm{~min}$. The supernatants were transferred into clean $2 \mathrm{ml}$ centrifuge tubes containing $750 \mu \mathrm{l}$ of isopropanol. Samples were incubated at room temperature for $10 \mathrm{~min}$ and the precipitated DNA was pelleted by centrifugation at 
$10000 \times g$ for $10 \mathrm{~min}$. The DNA pellets were washed once with $70 \%$ ethanol, air-dried, and then resuspended in $100 \mu \mathrm{l}$ of TE buffer (Tillett \& Neilan 2000). Samples were stored at $-20^{\circ} \mathrm{C}$ until analysis. DNA concentrations were quantified by PicoGreen ${ }^{\circledR}$ DNA quantification (Molecular Probes) using a spectral fluorometer following the manufacturer's specifications.

To assess the diversity of nifH-containing plankton at Stn ALOHA, samples from 9 depths in the upper $200 \mathrm{~m}$ were PCR-amplified using degenerate nifH primers (Zehr \& Turner 2001, Steward et al. 2004). The resulting PCR products were cloned and sequenced following the protocol described in Zehr \& Turner (2001). Briefly, a 2-step, nested PCR strategy was utilized to amplify a $359 \mathrm{bp}$ region of the nifH gene (Zehr \& McReynolds 1989). For the first round of the PCR, $2 \mathrm{ng}$ of environmental DNA were added to $50 \mu \mathrm{PCR}$ reactions. After 30 cycles of PCR amplification, $2 \mu \mathrm{l}$ of the first-round PCR products were added to $50 \mu \mathrm{l}$ second-round PCR reactions and amplified for an additional 30 cycles. The resulting PCR products were visualized on an ethidium bromide-stained $1.2 \%$ agarose gel, excised, and purified using a QIAEX II kit (Qiagen). PCR-amplified DNA was cloned into P-GEM T vector (Promega), transformed in Escherichia coli JM109 competent cells, and identified by bluewhite screening. Recombinant plasmids were purified using a 96-well Montage miniprep kit (Millipore), and sequenced using Applied Biosystems Big Dye ${ }^{\mathrm{TM}}$ chemistry on an ABI 3100 (Applied Biosystems). Representative nifH groups were sequenced on both strands.

QPCR amplification and primer specificity. For development of QPCR probes and primers, we selected 4 representative nifH sequences that were retrieved from the PCR clone libraries. QPCR amplification requires an oligonucleotide probe that contains both a fluorescent (reporter) and a quenching dye; when the probe is in close proximity to the quenching dye, fluorescence is effectively quenched. For this study, probes were 5 '-labeled with the fluorescent reporter FAM (6-carboxyfluorescein) and 3'-labeled with TAMRA (6-carboxytetramethylrhodamine) as a quenching dye. During amplification, the probe is cleaved by the 5 '-exonuclease activity of the Taq DNA polymerase, separating the reporter from the quencher and resulting in fluorescence emission. Fluorescence yield in the QPCR reaction is directly proportional to PCR product accumulation, which depends on the amount of the initial product in each reaction.

Primers and probes (Table 1) were designed for 4 different nifH phylotypes, comprising the Group A and Group B unicellular cyanobacteria, Trichodesmium spp., and the Cluster III nifH phylotype using Primer Express software (Applied Biosystems). The Trichodesmium spp. QPCR primers and probes were designed to target $T$. thiebautti; however, the nifH sequences of Trichodesmium spp. and Katagnymene spp. are closely related (Lundgren et al. 2001), and the Trichodesmium spp. QPCR primers and probes used for this study also amplified nifH genes from $T$. erythraeum and $T$. thiebautti with equal efficiency (data not shown).

Triplicate $25 \mu \mathrm{l}$ QPCR reactions were conducted for each environmental DNA sample and for each standard. Reaction mixes contained $1 \times$ TaqMan $^{\circledR}$ PCR buffer (Applied Biosystems), $2.0 \mathrm{mM} \mathrm{MgCl} 2,200 \mu \mathrm{M}$ each of dATP, dGTP, dCTP and $400 \mu \mathrm{M}$ dUTP, $400 \mathrm{nM}$ each of forward and reverse primer, $200 \mathrm{nM}$ of fluorogenic probe, $0.25 \mathrm{U}$ of AmpErase uracyl Nglycosylase (UNG), 0.625 U AmpliTaq gold DNA polymerase (Applied Biosystems). To each reaction, $2 \mu \mathrm{l}$ of environmental DNA or plasmid standards were added equivalent to 2-6 ng additions of environmental DNA. A GeneAmp ${ }^{\circledR} 5700$ (Applied Biosystems) was used for quantitative detection of amplified PCR products. Thermal cycling conditions were $50^{\circ} \mathrm{C}$ for $2 \mathrm{~min}, 95^{\circ} \mathrm{C}$ for $10 \mathrm{~min}$, and 45 cycles $\left(95^{\circ} \mathrm{C}\right.$ for $15 \mathrm{~s}$ followed by $60^{\circ} \mathrm{C}$ for $\left.1 \mathrm{~min}\right)$.

The specificities of each QPCR primer/probe set were evaluated using non-target controls (plasmids containing non-target nifH inserts) in QPCR reactions and comparing the amplification cycle threshold $(\mathrm{Ct})$ to plasmids containing the target nifH insert. The nontarget controls used for the Group A primers and probes were non-target nifH PCR products cloned from Group B cyanobacteria (AF299418; $80 \%$ identical nifH DNA), and Trichodesmium spp. (AY528677; $75 \%$ identical nifHDNA); Group B non-target controls were cloned Group A (AF059642; 80\% identical nifH DNA), and Trichodesmium spp. (77\% identical nifH DNA) nifH fragments. Similarly, non-target controls for the Trichodesmium spp. probes and primers were cloned nifH PCR products from the Group A and B cyanobacteria. The non-target control for the Cluster III sequence was a cloned nifH PCR product (84\% similar nifH DNA) from an uncultivated Cluster III phylotype recovered from a microbial mat in Baja, Mexico (AY232376), as well as the nifH PCR products cloned from the Group A, B, and Trichodesmium spp. phylotypes (Table 1).

Standard curves and PCR inhibition. Standards for each $\mathrm{TaqMan}^{\circledR}$ primer/probe set consisted of serial dilutions of the positive controls (plasmids with the target nifH inserts). To create standard curves of $\mathrm{Ct}$ versus amount of nifH target added to each reaction, $2 \mu \mathrm{l}$ of each plasmid dilution were added to duplicate QPCR reactions. Additions of nifH genes for standard curves ranged from $<10$ to $>10^{6}$ nifH copies per reaction. Least-squares linear regression analyses of $\mathrm{Ct}$ versus $\log _{10}$ nifH gene copies were used to quantify the target genes in the environmental DNA samples. 


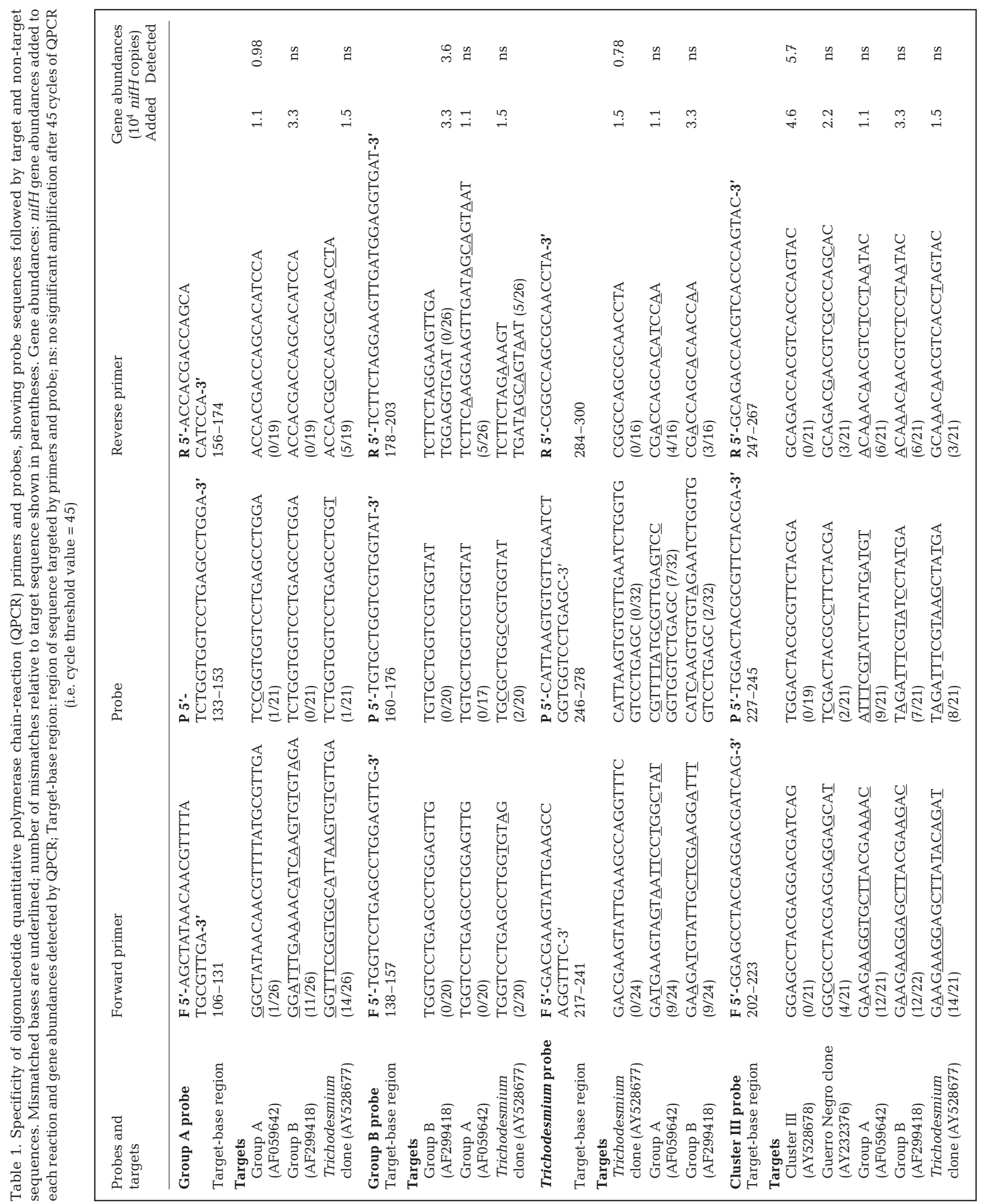


Model I linear regression analyses were performed using Sigma Plot Version 8.0 (SPSS).

To assess potential influences of PCR inhibition on amplification of environmental samples, duplicate QPCR reactions from each environmental sample were spiked with $0.5 \mathrm{pg}$ positive-control DNA (plasmids containing the target nifH PCR product). An increase in the $\mathrm{Ct}$ of the positive control due to inhibition by environmental samples was detected by comparison with the Ct of the positive control alone. Several experiments were also conducted to determine if the measured QPCR signal was proportional to the amount of environmental DNA added to the reaction. In these experiments, varying additions of environmental DNA (0.1 to $24 \mathrm{ng}$ DNA) were added to triplicate $25 \mu \mathrm{l}$ QPCR reactions and the resulting $\mathrm{Ct}$ values were evaluated to determine if the signal was proportional to the sample added.

Biogeochemical parameters. Chlorophyll a concentrations were determined by filtering $125 \mathrm{ml}$ seawater samples onto Whatman $25 \mathrm{~mm}$ GF/F filters (Whatman) and extracting samples in $90 \%$ acetone; concentrations were determined fluorometrically using a Turner AU-10 fluorometer (Turner). PE concentrations were measured from size-fractionated plankton samples following a protocol described by Wyman (1992), as modified by Dore et al. (2002). Briefly, whole seawater was size-fractionated onto 10.0, 5.0, and $0.4 \mu \mathrm{m}$ filters; PE was extracted from the filters, and concentrations were determined fluorometrically. To capture suspended particles, 101 of seawater were sequentially pressure filtered onto $25 \mathrm{~mm}$ diameter $10.0 \mu \mathrm{m}$ poresize Nitex screening and $5.0 \mu \mathrm{m}$ polycarbonate filters (Millipore). Next, $1 \mathrm{l}$ from each of the $<5.0 \mu \mathrm{m}$ filtrates was vacuum-filtered onto $25 \mathrm{~mm}$-diameter, $0.4 \mu \mathrm{m}$ pore-size polycarbonate filters (Millipore). Filters were placed in $20 \mathrm{ml}$ scintillation vials containing $5 \mathrm{ml}$ of a saline-glycerol solution (35 $\left.\mathrm{g} \mathrm{l}^{-1} \mathrm{NaCl}\right)$, and stored frozen until processed in the laboratory. In the laboratory, scintillation vials were placed on an orbital shaker table to resuspend particulate material from the filters, and the in vivo fluorescence of the resuspended particles was determined on the same Turner AU-10 fluorometer (544 nm excitation and $577 \mathrm{~nm}$ emission) used for chlorophyll determinations.

The abundances of Prochlorococcus spp., Synechococcus spp. and non-pigmented prokaryotes were enumerated by flow cytometry using the methods described in Monger \& Landry (1993) and Campbell \& Vaulot (1993). Briefly, $1 \mathrm{ml}$ seawater samples were added to cryovials (Corning) containing $0.02 \mathrm{ml}$ of $10 \%$ paraformaldehyde, and samples were quickfrozen in liquid nitrogen. For analyses, samples were thawed and stained for $2 \mathrm{~h}$ with the fluorochrome Hoechst 33342 (Molecular Probes). Cell concentrations were then enumerated on a Coulter EPICS dual laser (1 W $488 \mathrm{~nm}$ and $225 \mathrm{~mW}$ UV) flow-cytometer (Beckman Coulter). The flux of photosynthetically available radiation (PAR, 400 to $700 \mathrm{~nm}$ ) was determined from measurements of downwelling irradiance; profiles were collected using a Biospherical Instruments Profiling Reflectance Refractometer (PRR 600) (Biospherical Instruments). Upper-ocean $\left[\mathrm{NO}_{3}{ }^{-}+\mathrm{NO}_{2}^{-}\right]$was determined using the chemiluminescent detection system described by Garside (1982) and Dore \& Karl (1996).

\section{RESULTS}

\section{Upper-ocean biogeochemical characteristics and degenerate nifH PCR}

Based on data collected on a Hawaii Ocean time-series (HOT) program cruise to Stn ALOHA on December 17 to 21,2002 (approximately coincident with this study), the average surface mixed layer based on the 0.125 potential density criterion (Monterey \& Levitus 1997) was $82 \mathrm{~m}$, and the base of the photic zone $(1 \%$ surface isopleth for PAR) was $108 \mathrm{~m}$ (Fig. 1A). Mixed-layer temperatures averaged $24.7^{\circ} \mathrm{C}$ and decreased to $23.1^{\circ} \mathrm{C}$ at the base of the photic zone. Mixed-layer $\left[\mathrm{NO}_{3}{ }^{-}+\mathrm{NO}_{2}{ }^{-}\right]$averaged $2.5 \mathrm{nmol} \mathrm{N} \mathrm{^{-1 }}$, increasing to $>300 \mathrm{nmol} \mathrm{N} \mathrm{l}^{-1}$ at $100 \mathrm{~m}$ (Fig. 1A). Concentrations of DNA extracted from the $<10 \mu \mathrm{m}$ plankton size classes ranged between 0.18 and $1.5 \mu_{\text {DNA }}{ }^{-1}$ (Fig. 1A).

The abundance of non-pigmented picoplankton was nearly constant throughout the mixed layer, averaging $6.7 \times 10^{8}$ cells $^{-1}$, declining more than 2 -fold beneath the photic zone (Fig. 2A). Similarly, the depth distributions of Prochlorococcus spp. and Synechococcus spp. were also approximately constant in the mixed layer, averaging $1.3 \times 10^{8}$ and $2.4 \times 10^{6}$ cells s $^{-1}$, and declining 76 and $90 \%$, respectively, toward the base of the photic zone. Depth-integrated (0 to $100 \mathrm{~m}$ ) abundances of non-pigmented picoplankton, Prochlorococcus spp., and Synechococcus spp. were $3.9 \times 10^{13}, 1.7 \times 10^{13}$, and $1.9 \times 10^{11}$ cells $\mathrm{m}^{-2}$, respectively. Vertical profiles of size-fractionated PE revealed the greatest concentrations to be associated with the $<10$ to $0.4 \mu \mathrm{m}$ size fraction (Fig. 2B); concentrations in this size fraction were more than 1 order of magnitude greater than concentrations in the $>10 \mu \mathrm{m}$ size fraction. Concentrations of PE in the $<10 \mu \mathrm{m}$ size fraction averaged $5.8 \mathrm{ng} \mathrm{l}^{-1}$ in the top $60 \mathrm{~m}$ of the water column, decreasing roughly 5-fold toward the base of the photic zone (Fig. 2B). In contrast, concentrations of $>10 \mu \mathrm{m}$ PE were lower, varying from 0.2 and $2.1 \mathrm{ng} \mathrm{l}^{-1}$ throughout the mixed layer, and decreased to $\leq 0.1 \mathrm{ng} \mathrm{l}^{-1}$ by $100 \mathrm{~m}$.

nifH gene fragments were amplified from samples collected in the upper $175 \mathrm{~m}$ of the water (Fig. 1B). 

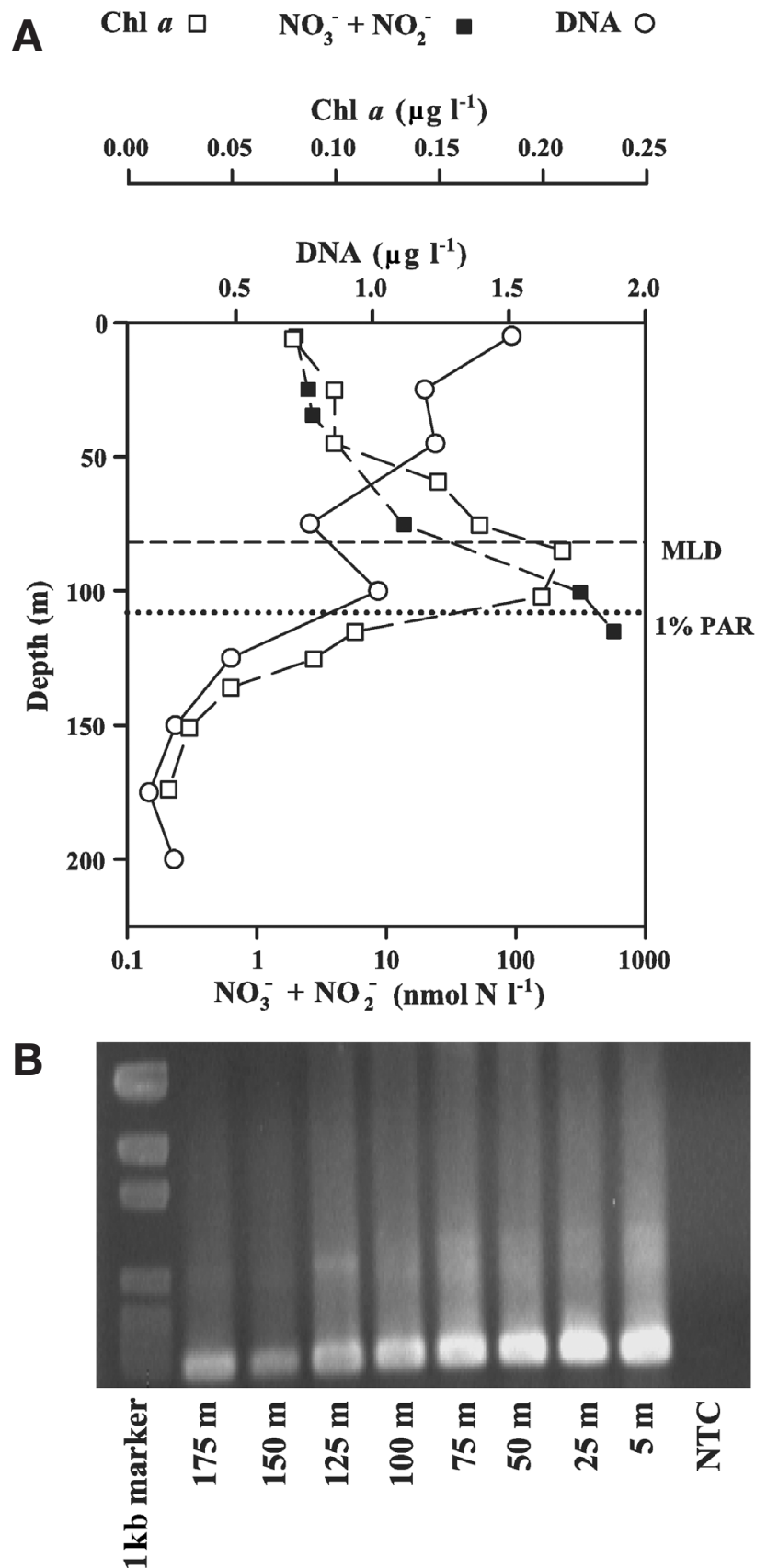

Fig. 1. (A) Depth profile of concentrations of extracted DNA, chlorophyll a $(\mathrm{Chl} a)$, and $\left[\mathrm{NO}_{3}{ }^{-}+\mathrm{NO}_{2}{ }^{-}\right]$at Stn ALOHA in December 2002; dashed line: base of surface mixed-layer depth (MLD; $0.125 \mathrm{U}$ potential density); dotted line: 1\% surface PAR isopleth. (B) Gel image of PCR-amplified nifH genes from depth profile at Stn ALOHA in December 2002; each PCR reaction contained 2 ng of environmental DNA; NTC: no template control

Phylotypes retrieved from the nifH PCR amplification and sequencing of the $<10 \mu \mathrm{m}$ plankton size class included several sequences $\geq 98 \%$ identical to the Group A (AF059642) and Group B cyanobacteria (AF299418) (Zehr et al. 2001). In addition, several
A

Non-pigmented prokaryotes
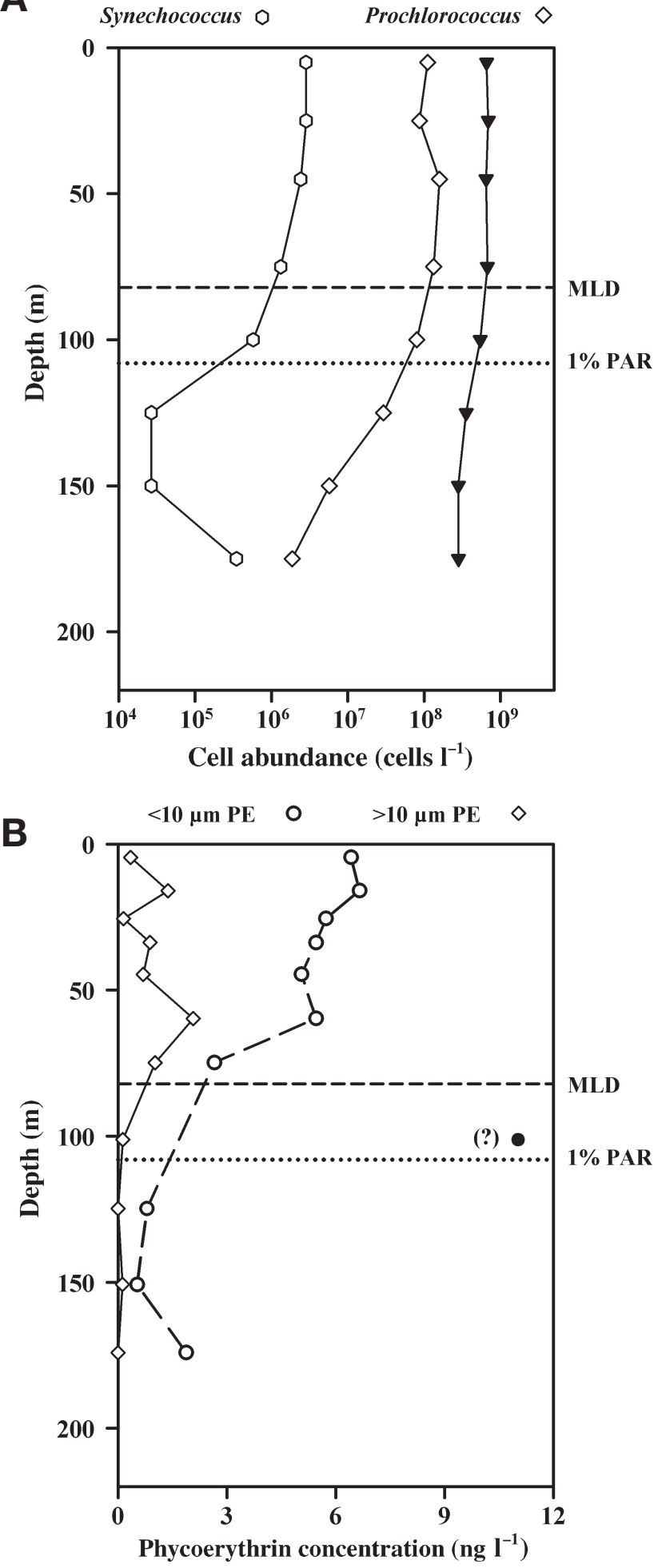

Fig. 2. (A) Vertical distributions of picoplankton abundances (based on flow-cytometry) and (B) concentrations of phycoerythrin (PE) extracted from various size fractions of suspended particles at Stn ALOHA in December 2002. Dashed line: base of MLD (0.125 U potential density); dotted line: $1 \%$ surface PAR isopleth; (?) questionable phycoerythrin data 
sequences similar (98 to $99 \%$ identical) to Trichodesmium thiebautii (U23507) and Katagnymene spiralis (AF395130) were obtained (Fig. 3A). Also retrieved from the $<10 \mathrm{~mm}$ plankton size class was a Cluster III nifH DNA sequence (Fig. 3B); this Cluster III nifH sequence had not previously been reported from the open ocean. Sequences grouping with the Cluster III nifH phylotypes include strict anaerobes such as Desulfovibrio spp., archaeal methanogens, and green sulfur bacteria (Young 1992, Zehr et al. 2003).

PCR amplification and sequencing of the $>10 \mu \mathrm{m}$ plankton size class revealed several phylotypes identical to sequences found in the $<10 \mu \mathrm{m}$ size class, including nifH DNA sequences $~ 98 \%$ identical to Trichodesmium thiebautii, and several sequences identical to the Group A and the novel Cluster III nifH phylotype. No nifH sequences closely related to the Group B cyanobacteria were found in the $>10 \mu \mathrm{m}$ plankton clone library.

\section{QPCR amplification of upper-ocean diazotrophs}

Amplification of standards was $\log _{10}$-linear across a range of target gene concentrations from $\sim 1$ to $10^{7}$ gene copies per reaction (Fig. 4A). The relationship between $\mathrm{Ct}$ and target nifH genes in the standards was also generally consistent among the 4 primer and probe sets (Fig. 4A). The least-squares linear regression of the standard curve for all phylotypes was $\mathrm{Ct}=-3.27$ $\left(\log _{10}\right.$ nifH gene copies $)+39.9\left(\mathrm{R}^{2}=0.95, \mathrm{p}<0.0001\right)$, with the coefficient of variation of the $\log _{10}$-transformed standards averaging $5 \%$.

The specificities of the QPCR primers and probes used in this study were tested by the addition of plasmids containing non-target, cloned nifH PCR products to QPCR reactions and evaluating whether any of the non-target nifH PCR products demonstrated crossreactivity with the QPCR probes and primers (Table 1).
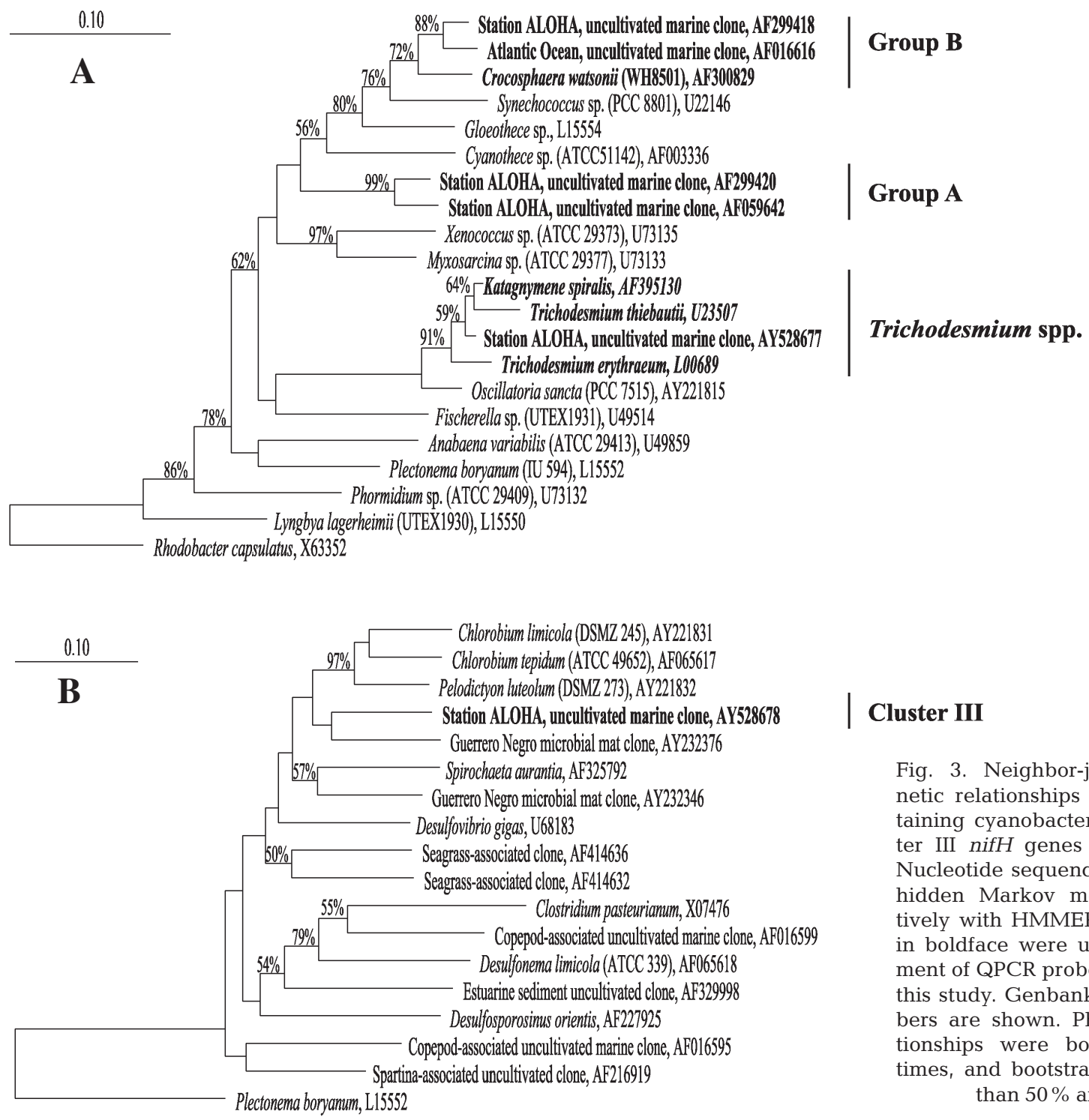

\section{Cluster III}

Fig. 3. Neighbor-joining phylogenetic relationships of (A) nifH-containing cyanobacteria and (B) Cluster III nifH genes at Stn ALOHA. Nucleotide sequences aligned using hidden Markov model built iteratively with HMMER 2.2. Sequences in boldface were used for development of QPCR probes and primers in this study. Genbank accession numbers are shown. Phylogenetic relationships were bootstrapped 1000 times, and bootstrap values greater than $50 \%$ are shown 

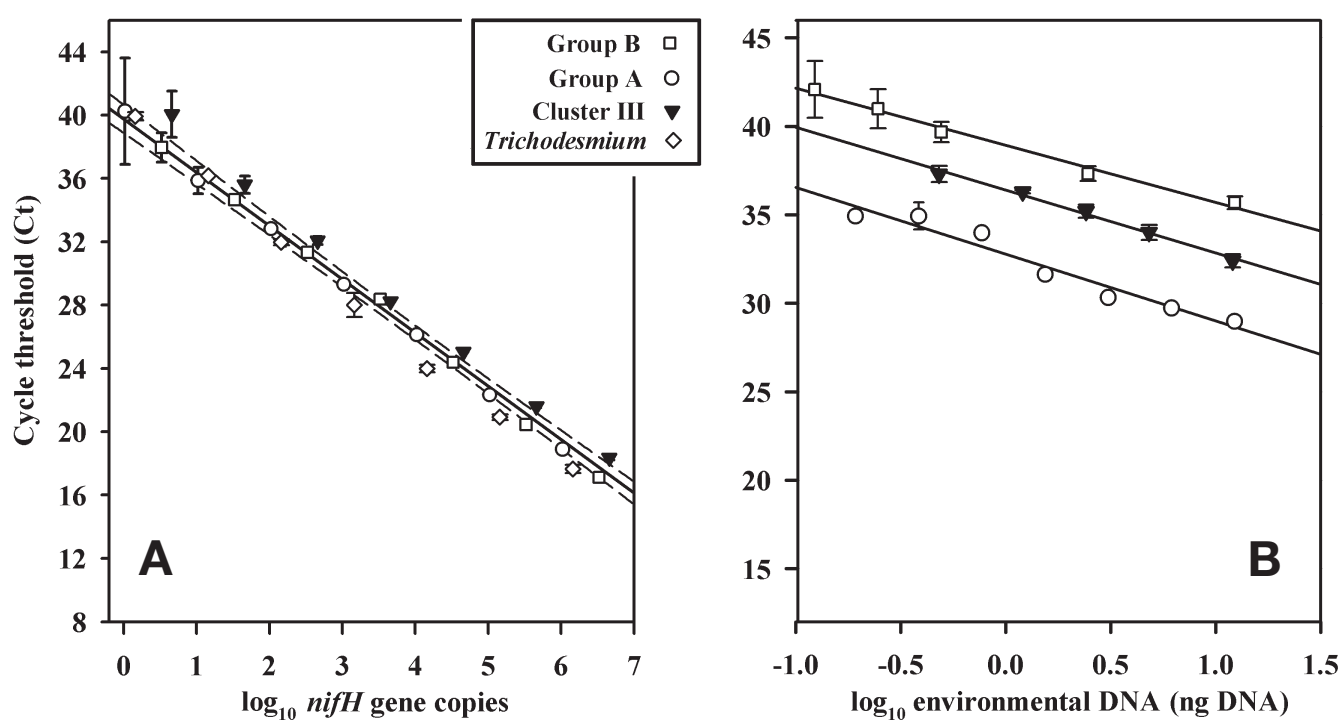

Fig. 4. (A) Standard curves of nifHQPCR probes and primers used in this study; continuous line: least-squares linear regression of amplification cycle threshold (Ct) versus logarithm of nifH gene copies; dashed lines: $95 \%$ confidence intervals of the regression; error bars are $\pm 1 \mathrm{SD}$ of mean of triplicate reactions. (B) Relationships between environmental DNA and amplification cycle

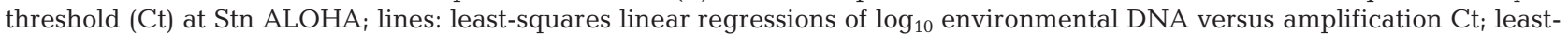
squares regression of Group B nifH phylotype is $\mathrm{Ct}=-2.84\left(\log _{10}\right.$ environmental DNA $)+38.7\left(\mathrm{R}^{2}=0.99\right.$, $\left.\mathrm{p}<0.0001\right)$; least-squares regression of Cluster III nifH phylotype is Ct $=-3.19\left(\log _{10}\right.$ environmental DNA $)+37.1\left(\mathrm{R}^{2}=0.99\right.$, $\left.\mathrm{p}<0.0001\right)$; least-squares regression of Group A nifH phylotype is $\mathrm{Ct}=-3.75\left(\log _{10}\right.$ environmental DNA $)+33.0\left(\mathrm{R}^{2}=0.95, \mathrm{p}<0.0001\right)$

When $<10^{5}$ non-target nifH gene copies were added to each reaction, no significant amplification was detected after 45 PCR cycles (Table 1). This procedure has a detection limit of $\sim 1$ nifH gene copy per reaction.

Overall, the presence of environmental DNA did not significantly alter the amplification of the plasmid positive controls, indicating that PCR inhibition did not influence the amplification of nifH DNA in the environmental samples. QPCR reactions containing DNA additions between 0.2 and 12 ng DNA demonstrated the predicted logarithmic relationship between target gene abundance and $\mathrm{Ct}$ (Fig. 4B), implying that within this range of DNA, the measured $\mathrm{Ct}$ values were proportional to the amount of DNA added to each reaction.

The relative abundances of all 4 nifH phylotypes demonstrated large variations with depth, with greater nifH gene abundances in the upper $50 \mathrm{~m}$ of the photic zone, declining substantially with depth (Fig. 5). The average mixed-layer abundance of the nifH gene from Group A cyanobacteria in the $<10 \mu \mathrm{m}$ plankton size class was $1 \times 10^{5}$ copies $\mathrm{l}^{-1}$, decreasing to $2 \times 10^{2}$ copies $\mathrm{l}^{-1}$ beneath the photic zone (Fig. 5A). Mixed-layer concentrations of Group A nifH genes in the $>10 \mu \mathrm{m}$ plank-

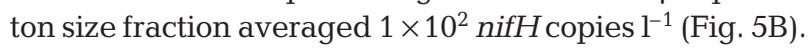

The abundance of Group B cyanobacteria in the $<10 \mu \mathrm{m}$ plankton size class was approximately 2 orders of magnitude less than Group A, averaging $2 \times 10^{3}$ nifH copies $\mathrm{l}^{-1}$ in the mixed layer, declining to $<3 \times$
$10^{2}$ copies $^{-1}$ below the photic zone (Fig. 5A). Trichodesmium spp. phylotypes were only detected by QPCR in the mixed layer from the $>10 \mu \mathrm{m}$ plankton size fraction (Fig. 5B). Mixed-layer abundance of Trichodesmium spp. averaged $4 \times 10^{3}$ copies $\mathrm{l}^{-1}$, becoming undetectable $(<1$ gene copy per reaction) below the photic zone (Fig. 5B). The Cluster III nifH phylotype in the $<10 \mu \mathrm{m}$ size class averaged $7 \times 10^{4}$ copies $\mathrm{l}^{-1}$ in the mixed layer, but beneath the photic zone the Cluster III nifH phylotype was the most abundant of the phylo-

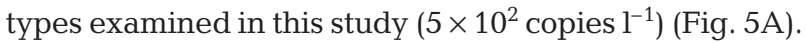
The Cluster III nifH phylotype was also detectable in the $>10 \mu \mathrm{m}$ plankton size class, but at low abundance (ranging from $5 \times 10^{2}$ to $1 \times 10^{2}$ copies $^{-1}$ ) (Fig. 5B). The sum of the depth-integrated gene abundances for all 4 nifH phylotypes was $\sim 1.5 \times 10^{10}$ nifH copies $\mathrm{m}^{-2}$.

\section{DISCUSSION}

While diverse species of oceanic microorganisms appear capable of $\mathrm{N}_{2}$-fixation (Zehr et al. 1998, 2001), to date there is little information on the abundance of specific diazotrophs in the open ocean. In this study, we utilized TaqMan ${ }^{\circledR}$ assays to quantify the abundance and vertical distributions of nifH genes corresponding to 4 upper-ocean nifH phylotypes. As employed in this study, detection of nifH genes indicates the genetic potential for $\mathrm{N}_{2}$ fixation. All 4 nifH phylotypes demon- 
Fig. 5. (A) Vertical profiles of $<10 \mu \mathrm{m}$ nifH phylotypes at Stn ALOHA in December 2002; dashed line: base of MLD (0.125 U potential density); dotted line: $1 \%$ surface PAR isopleth. (B) Vertical profiles of $>10 \mu \mathrm{m}$ nifH phylotypes; no amplification of Group B nifH phylotype was detected in $>10 \mu \mathrm{m}$ plankton size fraction after 45 QPCR cycles. Error bars are \pm 1 SD of triplicate QPCR reactions

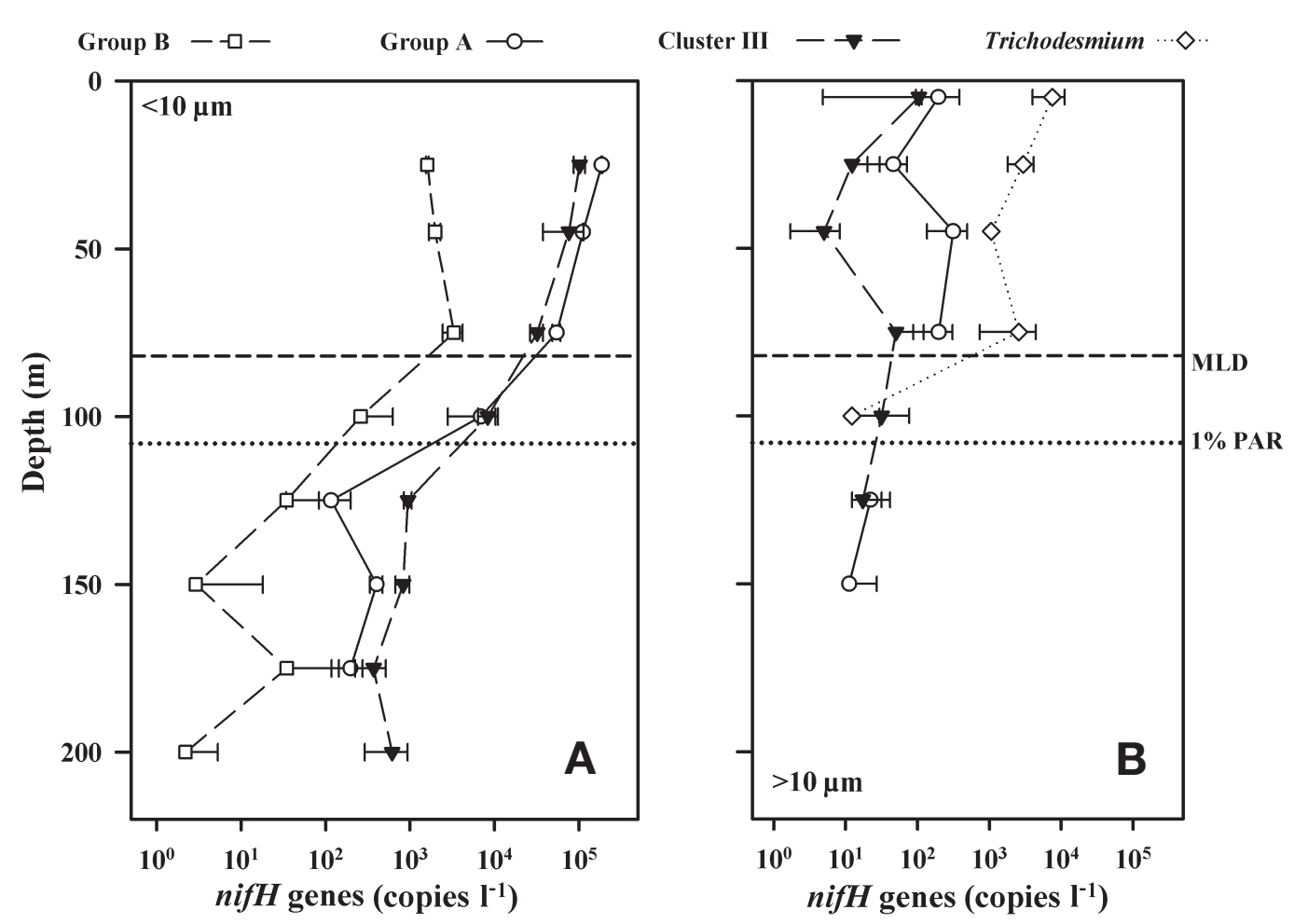

strated greatest abundances in the upper $45 \mathrm{~m}$, where $\left[\mathrm{NO}_{3}{ }^{-}+\mathrm{NO}_{2}^{-}\right]$averaged $2.5 \mathrm{nmol} \mathrm{N}{ }^{-1}$ and flux of light energy was high (68 to $700 \mu \mathrm{mol}$ quanta $\mathrm{m}^{-2} \mathrm{~s}^{-1}$ ). Gene abundances decreased significantly below the mixed layer, where $\left[\mathrm{NO}_{3}{ }^{-}+\mathrm{NO}_{2}^{-}\right]$increased more than 20fold, and light fluxes decreased to $<17 \mu \mathrm{mol}$ quanta $\mathrm{m}^{-2} \mathrm{~s}^{-1}$.

Among the nifH phylotypes examined by QPCR, the Group A and B cyanobacteria and the novel Cluster III phylotypes were most abundant in the smaller $(<10 \mu \mathrm{m})$ plankton size class. Trichodesmium spp. phylotypes were detected by QPCR in the $>10 \mu \mathrm{m}$ plankton size class at mixed-layer concentrations of $\sim 4 \times 10^{3}$ nifH gene copies $\mathrm{l}^{-1}$. Group A cyanobacteria, which phylogenetically cluster with unicellular cyanobacteria, were detected at low concentrations $(<3 \times$ $10^{2}$ gene copies $\mathrm{l}^{-1}$ ) in the $>10 \mu \mathrm{m}$ size class. Based on these results, we are unable to determine whether the Group A cells sometimes exceed $10 \mu \mathrm{m}$, or whether the cells exist as aggregates or aggregated during filtration. The Group A phylotypes could also occur as endosymbionts; Carpenter \& Janson (2000) observed unicellular cyanobacteria with 16S rDNA sequences similar to Cyanothece sp. (ATCC 51142) inside the diatom host Climacodium frauenfeldianum in both the tropical Pacific and Atlantic Oceans.

The use of QPCR to enumerate nifH gene abundances relies on several assumptions. Gene copy numbers are calculated relative to PCR standards and therefore assume that amplification of environmental DNA closely mimics amplification of the standards (Chandler 1998, Suzuki et al. 2000). Suzuki et al. (2000) demonstrated that quantification of gene targets in environmental DNA depends on selection of suitable standards. In the present study, most of the sequencetypes targeted by the QPCR were uncultivated; as a result, we derived our estimates of gene copy numbers from plasmids that contained the cloned nifH sequence-types.

Our estimates of nifH gene abundances also assume that the DNA extraction efficiency was complete and equal among the various organisms in the environmental samples. Suzuki et al. (2001) observed differences in percentages of phylotypes estimated by QPCR from samples collected on different filter matrices. These authors hypothesized that these differences may have resulted from variations in DNA extraction efficiency (Suzuki et al. 2001). We did not specifically examine the efficiency of DNA extraction from each sample; however, all samples were subjected to identical extraction procedures, and had equal volumes of seawater loaded onto the filters.

Previous investigations into the diversity of $\mathrm{N}_{2}$-fixing bacteria at Stn ALOHA have identified several distinct nifH sequence-types, including the Group A and B cyanobacteria (Zehr et al. 1998, 2001, Falcón et al. 2002, 2004). Consistent with those prior studies, PCR amplification and sequencing of the upper-ocean 
plankton assemblage in the present study revealed several nifH phylotypes, including sequences closely related to Trichodesmium spp., the previously identified Group A and B unicellular cyanobacteria, and a novel Cluster III nifH phylotype.

Both the Group A and B cyanobacteria have been shown to express nifH at Stn ALOHA, suggesting that these groups may be actively involved in $\mathrm{N}_{2}$-fixation (Zehr et al. 2001, Falcón et al. 2004). The Group B nifH DNA sequences are most similar (93 to $99 \%$ ) to the nifH DNA sequence of marine Crocosphaera watsonii, while Group A nifH DNA sequences are most closely aligned ( 82\%) with Cyanothece sp. (ATCC 51142). Both C. watsonii and Cyanothece sp. typically range from 2 to $10 \mu \mathrm{m}$ in diameter (Reddy et al. 1993, Rippka et al. 2001), and both appear to temporally decouple $\mathrm{N}_{2}$-fixation from photosynthesis (Sherman et al. 1998).

The recently sequenced genomes of Crocosphaera watsonii and Trichodesmium erythraeum indicate that each of these microorganisms contains a single nifH gene copy per genome (see www.jgi.doe.gov). Based on QPCR amplification, we estimate that the mixedlayer cellular abundances of Group B phylotype aver-

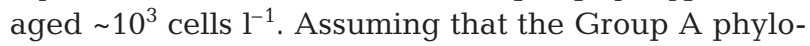
type also contains a single copy of nifH, mixed-layer Group A abundances would have averaged $\sim 10^{5}$ cells $\mathrm{l}^{-1}$. These abundance estimates are consistent with previous enumerations of 2 to $10 \mu \mathrm{m}$ unicellular, PEcontaining cyanobacteria in the oligotrophic Pacific Ocean. Ishizaka et al. (1994) observed a population of 2 to $4 \mu \mathrm{m}$ sized PE-containing coccoid cyanobacteria at concentrations ranging from $\sim 10^{5}$ to $10^{6}$ cells $\mathrm{l}^{-1}$ along a meridional survey between 14 and $26^{\circ} \mathrm{N}$ in the central North Pacific Ocean. Similarly, Campbell et al. (1997) found 3 to $5 \mu \mathrm{m}$ diameter Synechocystis sp.-like cells at Stn ALOHA at concentrations varying from $10^{3}$ to $10^{6}$ cells $^{-1}$. In the South Pacific, Neveux et al. (1999) observed 2 to $3 \mu \mathrm{m}$ diameter cyanobacteria at concentrations of $\sim 10^{5} \mathrm{cells}^{-1}$ in the upper $60 \mathrm{~m}$ of the water, and Falcón et al. (2004) estimated that the abundance of 3 to $7 \mu \mathrm{m}$ unicellular cyanobacteria at Stn ALOHA averaged $\sim 10^{4}$ cells l $^{-1}$.

Prior to the discovery of unicellular $\mathrm{N}_{2}$-fixing cyanobacteria, Trichodesmium spp. was believed to be the dominant marine diazotroph in the open ocean. Based on $3 \mathrm{yr}$ of microscopic enumerations, Letelier \& Karl (1996) estimated that Trichodesmium spp. abundance in the upper $45 \mathrm{~m}$ at Stn ALOHA ranged from $\sim 1 \times 10^{3}$ to $9 \times 10^{3}$ cells l$^{-1}$, consistent with previous reports (Carpenter 1983). Based on QPCR amplification of Trichodesmium spp. phylotypes, we estimate that the mixed-layer gene abundances of Trichodesmium spp. averaged $3 \times 10^{3}$ nifH copies $\mathrm{l}^{-1}$ during this cruise. These results suggest that, at times, the nifH gene abundances of the unicellular cyanobacterial Groups
A and B can be similar to or exceed that of Trichodesmium spp. Supporting these results, concentrations of the $<10 \mu \mathrm{m}$ PE-containing plankton were approximately 1 order of magnitude greater than the $>10 \mu \mathrm{m}$ size classes, suggesting that unicellular cyanobacteria were substantially more abundant than the larger filamentous, colony-forming cyanobacterium Trichodesmium spp. during this cruise.

In addition to evaluating the distributions of nifHcontaining cyanobacteria, we also quantified the abundance of a Cluster III nifH phylotype. Previous studies have retrieved Cluster III nifH sequences from PCR clone libraries for the open ocean. For example, Zehr et al. (1998) and Braun et al. (1999) found Cluster III nifH sequences in PCR-amplified DNA extracted from zooplankton biomass in the Gulf of Mexico and eastern Caribbean, leading these authors to hypothesize that oceanic invertebrates might host diazotrophs. To our knowledge, the present study is the first to have retrieved Cluster III nifH sequences from $<10 \mu \mathrm{m}$ plankton in the surface waters of the open ocean. Conceivably, the Cluster III nifH prokaryotes could exist in $\mathrm{O}_{2}$-reduced microenvironments in the upper ocean, e.g. attached to large particles or within the food vacuoles of microzooplankton. However, QPCR amplification of the Cluster III nifH gene in the $>10 \mu \mathrm{m}$ size fraction revealed low gene abundances $\left(<10^{2}\right.$ nifH copies $1^{-1}$ ).

Diazotrophic prokaryotes that phylogenetically group with the Cluster III nifH sequences include strict anaerobes such as Desulfovibrio spp., spirochetes, archaeal methanogens Methanosarcina spp., and phototrophic green-sulfur bacteria Chlorobium tepidum (Young 1992, Zehr et al. 2003). The depth distribution of the Cluster III phylotype resembles the depth distribution of the Crenarchaeota sp. at Stn ALOHA (Karner et al. 2001); however, the Cluster III nifH sequencetype clusters more closely with green-sulfur bacteria and the spirochetes than with archaeal nifH sequences. Moreover, a recent study characterizing the diversity of nifH phylotypes in the deep $(2200 \mathrm{~m})$ waters of the North Pacific found only Cluster II nifH phylotypes (Mehta et al. 2003). The Cluster III nifH sequences retrieved in this study could also have derived from green-sulfur bacteria; 16S rRNA sequences similar to those of Chlorobium spp. (SAR406) have been retrieved from the oligotrophic Sargasso Sea (Gordon \& Giovannoni 1996). Based solely on nifH sequence information and the phylotype depth distribution it is difficult to judge the ecological and biogeochemical significance of this Cluster III phylotype.

Unicellular $\mathrm{N}_{2}$-fixing bacteria may serve an important role in the introduction of new $\mathrm{N}$ to open-ocean microbial food webs. Unicellular plankton populations appear tightly regulated by top-down control (Caron et 
al. 1991, Landry \& Kirchman 2002); such trophodynamic pressures could support a significant fraction of nutrient regeneration in the upper ocean. Trophic transfer of $\mathrm{N}$ fixed by diazotrophic bacteria may provide a source of $\mathrm{N}$ that partly supports microbial food webs. Moreover, the low surface-area-to-volume ratio of unicellular cyanobacteria probably facilitates their ability to compete for nutrients in the oligotrophic ocean. While episodic blooms by large colonial cyanobacteria such as Trichodesmium spp. and diatoms with endosymbiotic $\mathrm{N}_{2}$-fixing cyanobacteria undoubtedly support a significant fraction of export productivity at Stn ALOHA (Letelier \& Karl 1996, Karl et al. 1997), the occurrence of these blooms appears linked to aeolian iron deposition (Karl 2002, Karl et al. 2003); the relatively small size of unicellular diazotrophs may enable sustained $\mathrm{N}_{2}$-fixation in the absence of infrequent dust-deposition events, and provide a regular source of $\mathrm{N}$ to upper-ocean microbial food webs.

Acknowledgements. We are grateful to the captain and crew of the RV 'Kilo Moana' for assistance at sea. We thank R. R. Bidigare (University of Hawaii) for organizing the research cruise and extending the opportunity for us to participate in this special-focus HOT cruise. S. M. Short, C. M. Short, and E. O. Omoregie provided insights into the nifH QPCR assays. This project was supported by NSF grants to J.P.Z. (OCE 9977460 and OCE 0132638) and D.M.K. (OCE 0326616).

\section{LITERATURE CITED}

Braun ST, Proctor LM, Zani S, Mellon MT, Zehr JP (1999) Molecular evidence for zooplankton-associated nitrogenfixing anaerobes based on amplification of the nifH gene. FEMS Microbiol Lett 28:273-279

Campbell L, Vaulot D (1993) Photosynthetic picoplankton community structure in the subtropical North Pacific-Ocean near Hawaii (Stn ALOHA). Deep-Sea Res I 40:2043-2060

Campbell L, Liu H, Nolla HA, Vaulot D (1997) Annual variability of phytoplankton and bacteria in the subtropical North Pacific Ocean at Station ALOHA during the 1991-1994 ENSO event. Deep-Sea Res I 44:167-192

Capone DG, Zehr JP, Paerl HW, Bergman B, Carpenter EJ (1997) Trichodesmium, a globally significant marine cyanobacterium. Science 276:1221-1229

Caron DA, Lim EL, Miceli G, Waterbury JB, Valois FW (1991) Grazing and utilization of chroococcoid cyanobacteria and heterotrophic bacteria by protozoa in laboratory cultures and a coastal plankton community. Mar Ecol Prog Ser 76: 205-217

Carpenter EJ (1983) Nitrogen fixation by marine Oscillatoria (Trichodesmium) in the world's oceans. In: Carpenter EJ, Capone DG (eds) Nitrogen in the marine environment. Academic Press, New York, p 65-103

Carpenter EJ, Janson S (2000) Intracellular cyanobacterial symbionts in the marine diatom Climacodium frauenfeldianum (Bacillariophyceae). J Phycol 36:540-544

Carpenter EJ, Montoya JP, Burns J, Mulholland MR, Subramaniam A, Capone DG (1999) Extensive bloom of a $\mathrm{N}_{2}-$ fixing diatom/cyanobacterial association in the tropical
Atlantic Ocean. Mar Ecol Prog Ser 185:273-283

Chandler DP (1998) Redefining relativity: quantitative PCR at low template concentrations for industrial and environmental microbiology. J Ind Microbiol Biotechnol 21: $128-140$

Deutsch C, Gruber N, Key RM, Sarmiento JL, Ganachaud A (2001) Denitrification and $\mathrm{N}_{2}$ fixation in the Pacific Ocean. Global Biogeochem Cycles 15:483-506

Dore JE, Karl DM (1996) Nitrification in the euphotic zone as a source for nitrite, nitrate, and nitrous oxide at Station ALOHA. Limnol Oceanogr 41:1619-1628

Dore JE, Brum JR, Tupas LM, Karl DM (2002) Seasonal and interannual variability in sources of nitrogen supporting export in the oligotrophic subtropical North Pacific Ocean. Limnol Oceanogr 47:1595-1607

Dugdale RC, Goering JJ (1967) Uptake of new and regenerated forms of nitrogen in primary productivity. Limnol Oceangr 12:196-206

Eppley RW, Peterson BJ (1979) Particulate organic-matter flux and planktonic new production in the deep ocean. Nature 282:677-680

Falcón LI, Cipriano F, Chistoserdov AY, Carpenter EJ (2002) Diversity of diazotrophic unicellular cyanobacteria in the tropical North Atlantic Ocean. Appl Environ Microbiol 68: 5760-5764

Falcón LI, Carpenter EJ, Cipriano F, Bergman B, Capone DG (2004) $\mathrm{N}_{2}$ fixation by unicellular bacterioplankton from the Atlantic and Pacific oceans: phylogeny and in situ rates. Appl Environ Microbiol 70:765-770

Falkowski PG (1997) Evolution of the nitrogen cycle and its influence on the biological sequestration of $\mathrm{CO}_{2}$ in the ocean. Nature 387:272-275

Garside C (1982) A chemiluminescent technique for the determination of nanomolar concentrations of nitrate and nitrite in sea-water. Mar Chem 11:159-167

Gordon DA, Giovannoni SJ (1996) Detection of stratified microbial populations related to Chlorobium and Fibrobacter species in the Atlantic and Pacific Oceans. Appl Environ Microbiol 62:1171-1177

Gruber N, Sarmiento JL (1997) Global patterns of marine nitrogen fixation and denitrification. Global Biogeochem Cycles 11:235-266

Ishizaka J, Kiyosawa H, Ishida $\mathrm{K}$, Ishikawa $\mathrm{K}$, Takahashi M (1994) Meridional distribution and carbon biomass of autotrophic picoplankton in the Central North Pacific Ocean during late northern summer 1990. Deep-Sea Res I 41:1745-1766

Karl DM (1999) A sea of change: biogeochemical variability in the North Pacific Subtropical Gyre. Ecosystems 2:181-214

Karl DM (2002) Nutrient dynamics in the deep blue sea. Trends Microbiol 10:410-418

Karl DM, Letelier R, Tupas L, Dore J, Christian J, Hebel D (1997) The role of nitrogen fixation in biogeochemical cycling in the subtropical North Pacific Ocean. Nature 388:533-538

Karl DM, Bates NR, Emerson S, Harrison PJ and 9 others (2003) Temporal studies of biogeochemical processes determined from ocean time-series observations during the JGOFS era. In: Fasham MJ (ed) Ocean biogeochemistry: the role of the ocean carbon cycle in global change. Springer-Verlag, Berlin, p 239-267

Karner MB, DeLong EF, Karl DM (2001) Archaeal dominance in the mesopelagic zone of the Pacific Ocean. Nature 409: 507-510

Landry MR, Kirchman DL (2002) Microbial community structure and variability in the tropical Pacific. Deep-Sea Res II 49:2669-2693 
Lee K, Karl DM, Wanninkhof R, Zhang JZ (2002) Global estimates of net carbon production in the nitrate-depleted tropical and subtropical oceans. Geophys Res Lett 29:doi: 10.1029/2001GLO14198

Letelier RM, Karl DM (1996) Role of Trichodesmium spp. in the productivity of the subtropical North Pacific Ocean. Mar Ecol Prog Ser 133:263-273

Letelier RM, Karl DM, Abbott MR, Flament P, Freilich M, Lukas R, Strub T (2000) Role of late winter mesoscale events in the biogeochemical variability of the upper water column of the North Pacific Subtropical Gyre. J Geophys Res C 105:28723-28739

Lundgren P, Soderback E, Singer A, Carpenter EJ, Bergman B (2001) Katagnymene: characterization of a novel marine diazotroph. J Phycol 37:1052-1062

Mehta MP, Butterfield DA, Baross JA (2003) Phylogenetic diversity of nitrogenase (nifH) genes in the deep-sea and hydrothermal vent environments of the Juan de Fuca ridge. Appl Environ Microbiol 69:960-970

Michaels AF, Olson D, Sarmiento JL, Ammerman JW and 5 others (1996) Inputs, losses and transformations of nitrogen and phosphorus in the pelagic North Atlantic Ocean. Biogeochemistry 35:181-226

Monger BC, Landry MR (1993) Flow cytometric analysis of marine-bacteria with Hoechst 33342. Appl Environ Microbiol 59:905-911

Monterey G, Levitus S (1997) Seasonal variability of mixed layer depth for the world ocean. NOAA Atlas NESDIS 14, US Government Printing Office, Washington, DC

Montoya JP, Holl CM, Zehr JP, Hansen A, Villareal TA, Capone DG (2004) High rates of $\mathrm{N}_{2}$-fixation by unicellular diazotrophs in the oligotrophic Pacific. Nature 430: $1027-1032$

Neveux J, Lantoine F, Vaulot D, Marie D, Blanchot J (1999) Phycoerythrins in the southern tropical and equatorial Pacific Ocean: evidence for new cyanobacterial types. J Geophys Res C 104:3311-3321

Reddy KJ, Haskell JB, Sherman DM, Sherman LA (1993) Unicellular, aerobic nitrogen-fixing cyanobacteria of the genus Cyanothece. J Bacteriol 175:1284-1292

Rippka R, Castenholz RW, Waterbury JB, Herdman M (2001) Form-genus V. Cyanothece. In: Garrity GM (ed) Bergey's manual of systematic bacteriology, Vol 2. Springer-Verlag, New York, p 501

Sakamoto CM, Karl DM, Jannasch HW, Bidigare RR and 5 others (2004) Influence of Rossby waves on nutrient dynamics and the plankton community structure in the North Pacific subtropical gyre. J Geophys Res Oceans 109; C05032, doi: 10:1029/2003JCOO1976

Sherman LA, Meunier P, Colon-Lopez MS (1998) Diurnal rhythms in metabolism: a day in the life of a unicellular, diazotrophic cyanobacterium. Photosynth Res 58:25-42

Short SM, Jenkins BD, Zehr JP (2004) The spatial and temporal distribution of two diazotrophic bacteria in the

Editorial responsibility: David Caron,

Los Angeles, California, USA
Chesapeake Bay. Appl Environ Microbiol 70:2186-2192

Steward GF, Zehr JP, Jellison R, Montoya JP, Hollibaugh JT (2004) Vertical distribution of nitrogen-fixing phylotypes in a meromictic, hypersaline lake. Microb Ecol 46:30-40

Suzuki MT, Taylor LT, DeLong EF (2000) Quantitative analysis of small-subunit rRNA genes in mixed microbial populations via 5'-nuclease assays. Appl Environ Microbiol 66:4605-4614

Suzuki MT, Preston CM, Chavez FP, DeLong EF (2001) Quantitative mapping of bacterioplankton populations in seawater: field tests across an upwelling plume in Monterey Bay. Aquat Microb Ecol 24:117-127

Tillett D, Neilan BA (2000) Xanthogenate nucleic acid isolation from cultured and environmental cyanobacteria. J Phycol 36:251-258

Venrick EL (1974) The distribution and significance of Richelia intracellularis Schmidt in the North Pacific Central Gyre. Limnol Oceangr 19:437-445

Villareal TA (1991) Nitrogen-fixation by the cyanobacterial symbiont of the diatom genus Hemiaulus. Mar Ecol Prog Ser 76:201-204

Weare NM, Azam F, Mague TH, Holm-Hansen O (1974) Microautoradiographic studies of the marine phycobionts Rhizosolenia and Richelia. J Phycol 10:369-371

Wyman M (1992) An in vivo method for the estimation of phycoerythrin concentrations in marine cyanobacteria (Synechococcus spp.). Limnol Oceangr 37:1300-1306

Young JPW (1992) Phylogenetic classification of nitrogenfixing organisms. In: Stacey G, Burris RH, Evans HJ (eds) Biological nitrogen fixation. Chapman \& Hall, New York, p 43-86

Zehr JP, Capone DG (1996) Problems and promises of assaying the genetic potential for nitrogen fixation in the marine environment. Microb Ecol 32:263-281

Zehr JP, McReynolds LA (1989) Use of degenerate oligonucleotides for amplification of the nifH gene from the marine cyanobacterium Trichodesmium thiebautii. Appl Environ Microbiol 55:2522-2526

Zehr JP, Turner PJ (2001) Nitrogen fixation: nitrogenase genes and gene expression. In: Paul JH (ed) Methods in microbiology, Vol 30. Academic Press, San Diego, CA, p 271-286

Zehr JP, Mellon MT, Zani S (1998) New nitrogen-fixing microorganisms detected in oligotrophic oceans by amplification of nitrogenase (nifH) genes. Appl Environ Microbiol 64:3444-3450

Zehr JP, Waterbury JB, Turner PJ, Montoya JP, Omoregie E, Steward GF, Hansen A, Karl DM (2001) Unicellular cyanobacteria fix $\mathrm{N}_{2}$ in the subtropical North Pacific Ocean. Nature 412:635-638

Zehr JP, Jenkins BD, Short SM, Steward GF (2003) Nitrogenase gene diversity and microbial community structure: a cross-system comparison. Environ Microbiol 5: $539-554$

Submitted: March 8, 2004; Accepted: August 15, 2004

Proofs received from author(s): December 27, 2004 